dowiska przyrodniczego do strategii jego wykorzystania poprzez zagospodarowanie turystyczno-rekreacyjne. Kolejnym ważnym zadaniem jest rozpoznanie uwarunkowań i możliwości aktywizacji turystyki osób niepełnosprawnych. W celu porozumiewania się z grupa turystów niesłyszących opracowano Multimedialny podręcznik do nauki języka migowego dla potrzeb turystyki i rekreacji (2003 r.).

Do aktualnie realizowanych w Centrum projektów badawczych należą: „Narciarstwo wodne” praca pod kierunkiem prof. dr hab. Zygmunta Młynarczyka; „Wpływ wyciagów narciarskich nart wodnych na dotlenienie jezior i atrakcyjność turystyczną na przykładzie jeziora Necko w Augustowie” - mgr Krzysztof Piotrowski; „Zróżnicowanie przestrzeni turystycznej rynien jezior kórnicko-zaniemyskich i jezior pszczewskich" - mgr I. Potoc$\mathrm{ka}$, ,Aktywizacja rozwoju turystyki w dolinie Obry” - mgr A. Przybylska, ,Turystyka osób niesłyszących i możliwości jej aktywizacji poprzez zastosowanie multimedialnego systemu informacji turystycznej” - dr Alina Zajadacz, „Uwarunkowania i plany rozwoju turystyki" - praca zbiorowa pod redakcja prof. dr hab. Zygmunta Młynarczyka i dr Aliny Zajadacz.

W roku 2008 planowane jest powołanie branżowego czasopisma naukowego „Turystyka”, które będzie forum interdyscyplinarnych dyskusji przedstawicieli różnych dyscyplin naukowych zaangażowanych $\mathrm{w}$ badania nad turystyka.

Alina Zajadacz

\section{Geografia turyzmu w Uniwersytecie Gdańskim Instytut Geografii}

Działalność naukowo-badawcza i dydaktyczna z zakresu geografii turyzmu w Instytucie Geografii (powołanym w 2005 r.) skoncentrowana jest $w$ istniejących dwóch katedrach o profilu ekonomicznym: Katedrze Geografii Ekonomicznej (KGE) i Katedrze Rozwoju Regionalnego (KRR), a także w Katedrze Geografii Fizycznej i Ksztaltowania Środowiska.

W ramach działalności podstawowej związanej z kształceniem studentów na studiach magisterskich dziennych i zaocznych, licencjackich i magisterskich uzupełniających były prowadzone zajęcia w formie wykładów i ćwiczeń z geografii turystyki, nadmorskich regionów turystycznych tourism and recreation management. Another important task is to recognize the conditions and opportunities for developing tourism for disabled people. A multimedia handbook on sign language was developed in 2003 for the needs of tourism and leisure professionals to communicate with groups of deaf tourists.

The following research projects are undertaken in the Tourism and Leisure Centre: 'Water skiing' - managed by Prof. dr hab. Zygmunt Młynarczyk; The influence of water skiing on lake oxidation and tourist attractiveness: the example of Necko Lake in Augustôw (north-eastern Poland)' - Krzysztof Piotrowski M.Sc.; 'Differentiation of tourism spaces: Kórnik-Zaniemyśl and Pszczew Lakes' - Ilona Potocka M.Sc.; 'The activation of tourism development in the Obra river valley' - Anna Przybylska M.Sc.; The tourism of the deaf and opportunities activation using a tourist information multimedia system' - Dr Alina Zajadacz; 'Conditions and development plans for tourism' - collective research coordinated by Prof. dr hab. Zygmunt Młynarczyk \& Dr Alina Zajadacz.

In 2008, there are plans to create an academic journal 'Tourism', which would be a forum for interdisciplinary discussion for specialists representing the various disciplines involved in tourism and leisure studies.

Alina Zajadacz

\section{Geography of tourism at the University of Gdańsk Institute of Geography}

The academic, research and teaching activity of the Institute of Geography (which was established in 2005) in the field of tourism geography occurs in two existing departments with an economic basis (the Department of Economic Geography and the Department of Regional Development), and also in the Department of Physical Geography and Environmental Development.

The basic activity related to teaching regular and extramural students of Licencjat and Master's university programmes includes lectures and classes on the geography of tourism, coastal tourism regions and agro-tourism; Master's and Licencjat seminars; and local and regional fieldwork. Such subjects as tourism marketing and 
oraz agroturystyki, seminariów magisterskich i licencjackich oraz praktyk terenowych i regionalnych. Do programu nauczania na specjalności z geografii ekonomicznej wprowadzono przedmioty: marketing w turystyce oraz ekoturystykę.

W okresie od 1980 do stycznia 2005 r. wykonano $\mathrm{w}$ sumie 145 prac magisterskich i siedem licencjackich, w których podejmowane były aspekty przestrzenne szeroko rozumianej turysty$\mathrm{ki}, \mathrm{z}$ wyeksponowaniem procesów transformacji turystycznych struktur spoleczno-gospodarczych i przestrzennych obszarów nadmorskich Polski w warunkach wolnego rynku i procesie rozwoju samorządności. Większość tych prac (ponad 80\%) prowadzono w KGE, która posiada dhugie w tym zakresie tradycje (por. E. Andrzejewski, Badania $z$ zakresu geografii turyzmu, [w:] Problemy badawcze geografii turyzmu w Polsce w latach 1970 -1978, Zeszyty Naukowe UJ DCLII, Prace Geograficzne, z. 54, Kraków 1981, s. 11-18).

Znaczące ożywienie w badaniach turystycznych ośrodka nastapiło od roku 2002, gdy uzyskano status Centrum Doskonałości w ramach Piątego Programu Ramowego finansowanego przez Komisję Europejską i rozpoczęcie realizacji trzyletniego projektu badawczego RECOURSE. Badania skoncentrowano wokól produktów turystycznych województwa pomorskiego, problemów zagospodarowania i ruchu turystycznego, a także możliwości i zagrożeń turystyki w rozwoju lokalnym strefy nadmorskiej i podmiejskiej aglomeracji gdańskiej.

W okresie wcześniejszym (1996-2000) badania w zakresie turyzmu realizował dr Antoni Korowicki $w$ ramach badań wlasnych i realizowanych projektach (KBN Nr 1H02D 028 17/1999) „Strategia informatyzacji współczesnej organizacji", kierowanych przez prof. zw. dr hab. Bernarda F. Kubiaka $\mathrm{z}$ Wydziału Zarządzania Uniwersytetu Gdańskiego). Aktualnie prowadzone sa prace badawcze nad transformacją przestrzeni turystycznej Pojezierza Kaszubskiego, co stanowi przedmiot przygotowywanej rozprawy doktorskiej pisanej pod kierunkiem prof. UG dr hab. Iwony Sagan przez mgr. Michała Witkiewicza. Wyniki prowadzonych badań KGE $\mathrm{w}$ zakresie turystyki zamieszczone są $\mathrm{w}$ prestiżowych wydawnictwach zagranicznych i krajowych, co umożliwiło włączenie się do badań i rozwiązywania istotnych i aktualnych problemów przestrzennych polskiej turystyki. Szczególnie problemom strategii rozwoju turystyki w regionach wspomaganej nowoczesną technologią eco-tourism have been included in the teaching curriculum of economic geography.

In the period between 1980 and January 2005, a total of 145 Masters' theses and 7 Licencjat dissertations were written on spatial aspects of tourism, in the broader meaning of the term, with a focus on the socio-economic and spatial transformation of coastal areas in Poland in market economic conditions and processes of local government development.

Most of these studies were undertaken in the Department of Economic Geography which has a long tradition in this field (see publication by E. Andrzejewski, Badania $z$ zakresu geografii turyzmu, in: Problemy badaucze geografii turyzmu $w$ Polsce $w$ latach 1970-1978, Zeszyty Naukowe UJ DCLII, Prace Geograficzne, 54, Kraków 1981).

These had been supervised by Prof. Ewa Adrjanowska until 2001; Doc. Eugeniusz Andrzejewski until 1983; Prof. Jerzy J. Parysek, Dr Joanna Skupowa and Dr Antoni Korowicki, 1994-2002; Prof. Iwona Sagan since 2002 and Prof. Eamonn Judg since 2004.

Tourism-related studies by the Department have significantly increased since 2002 when the department was granted the status of an International Centre of Excellence under the Fifth Framework Programme financed by the EU, and a threeyear research project RE-COURSE was initiated. Research concentrated around the tourism products of Pomorskie Województwo, issues of tourism development and activity, as well as opportunities and threats to tourism development in the coastal zone and areas surrounding the Gdanisk.

Earlier (1996-2000) studies in tourism were carried out by Dr Antoni Korowicki as a part of his own research activity and under a KBN project (Nr 1H02D 028 17/1999) - Strategia informatyzacji wspótczesnej organizacji (The Contemporary Organization's Informatization Strategy) supervised by Prof. Bernard F. Kubiak from the Department of Management at the University of Gdansk.

Presently, intensive studies on the transformation of tourism space in the Kaszubian Lake District are taking place in the department. The subject has been taken up by Michał Witkiewicz (MSc) who is working on his doctoral thesis under the supervision of Prof. Iwona Sagan.

The outcomes of tourism-related studies in the department are presented in renowned foreign and Polish publications and this enables the department to contribute to research and ideas on important contemporary spatial problems of the tourism sector in Poland. Most attention and space has been given to issues of regional tourism strategic development, supported by modern information technology. Articles dedicated to this issue have been published in multi-media form 
informacji poświęcono najwięcej miejsca, a artykuły opublikowane są m.in. w postaci multimedialnej (CD ROM ISBN 80-7184-153-6) w czasopismach naukowych oraz innych opracowaniach i periodykach zagranicznych (USA, Chiny, Belgia, Holandia, Czechy), w publikacjach PAN, UW, PTG, TIP, Instytutu Badań Systemowych PAN, PTI, PTE oraz pracach różnych ośrodków akademickich (Gdańsk, Toruń, Wrocław, Szczecin, Poznań, Warszawa, Opole).

Antoni Korowicki

\section{Geografia turyzmu w Szkole Glównej Handlowej w Warszawie}

W Katedrze Geografii Ekonomicznej Szkoły Głównej Handlowej (SGH) zagadnienia $\mathrm{z}$ zakresu turystyki jako pierwszy podją prof. Stanisław Berezowski, nawiązując do dorobku swego promotora prof. Stanisława Leszczyckiego. Następnie problematyką turystyki zajmował się prof. Kazimierz Kuciński. Kontynuatorem prac prof. S. Berezowskiego i prof. K. Kucińskiego jest obecnie dr Marcin Molenda, zajmujący się rolą turystyki w rozwoju lokalnym oraz wykorzystaniem kapitału ludzkiego w turystyce. Doktor Molenda jest autorem licznych publikacji z zakresu geografii turystyki, w tym rozdziału o turystyce w Geografii ekonomicznej Unii Europejskiej. Prowadzi w SGH wykłady z zakresu geografii turystyki oraz seminaria licencjackie i magisterskie dotyczące regionalizacji turystycznej, a także wpływu turystyki na gospodarkę różnych krajów.

Od 1956 r. w SGH istnieje również Katedra Turystyki, która powstała jako Zakład Prawnych i Ekonomicznych Zagadnień Turystyki w Katedrze Prawa Międzynarodowego na Wydziale Handlu Zagranicznego. Pierwszym kierownikiem Zakładu (1956-1975) był prof. Kazimierz Libera, a następnie (1975-1994) doc. Olaf Rogalewski. Od 1994 r. Katedrą kieruje prof. Stanisław Wodejko.

W SGH funkcjonuje na studiach magisterskich kierunek „turystyka i rekreacja” ze specjalnością ,turystyka międzynarodowa” oraz „biznes turystyczny”. Prowadzone są też studia podyplomowe kształcące menadżerów turystyki.
(CD ROM: ISBN 80-7184-153-6), in academic journals and in international publications and periodicals (in the USA, China, Belgium, the Netherlands and the Czech Republic), in the publications of such Polish institutions as the Polish Academy of Science, the University of Warsaw, the Polish Geographical Society, TIP, the Institute of Systematic Studies of the Polish Academy of Science, the Polish Information Processing Society, the Polish Economic Society and in papers published by various academic centres (Gdańsk, Torun, Wrocław, Szczecin, Poznań, Warszawa and Opole).

Antoni Korowicki

\section{Geography of tourism at the Warsaw School of Economics}

In the Department of Economic Geography at the Warsaw School of Economics (WSE), research in tourism issues was started by Prof. Stanisław Bereżowski linked to the work of his former supervisor Prof. Stanisław Leszczycki, which was then continued by Prof. Kazimierz Kuciński. The projects initiated by Prof. Bereżowski and Prof. Kuciński are at present continued by Dr Marcin Molenda whose academic focus is on the role of tourism in local development and the use of human resources in tourism. He is the author of numerous publications on tourism geography including a chapter on tourism in Economic Geography in the European Union'. In WSE he lectures on tourism geography and has Licencjat and MA seminars on tourist regionalization and the influence of tourism on the economy of different countries.

Since 1956 WSE has also had a Department of Tourism which started as a research unit on the Legal and Economic Issues of Tourism, in the Department of International Law and Foreign Trade. The unit was first headed by Prof. Kazimierz Libera (1956-1975), then by Prof. Olaf Rogalewski (1975-1994), and since 1994 by Prof. Stanisław Wodejko.

Among its MA programmes, WSE offers a Master's degree in Tourism and Recreation with two specializations: International Tourism and Tourist Business. There are also postgraduate programmes in tourism management.

Marcin Molenda 